University of Nebraska - Lincoln

DigitalCommons@University of Nebraska - Lincoln

\title{
Antibacterial Activity of Cinnamaldehyde And Sporan Against Escherichia Coli 0157:H7 And Salmonella
}

\author{
Nadine Yossa \\ University of Maryland \\ Jitendra Patel \\ USDA-ARS, jitu.patel@ars.usda.gov \\ Dumitru Macarisin \\ USDA-ARS, dumitru.macarisin@ars.usda.gov \\ Patricia Millner \\ USDA-ARS, pat.millner@ars.usda.gov \\ Charles Murph \\ USDA-ARS, rachel.murph@co.usda.gov \\ See next page for additional authors
}

Follow this and additional works at: https://digitalcommons.unl.edu/usdaarsfacpub

Yossa, Nadine; Patel, Jitendra; Macarisin, Dumitru; Millner, Patricia; Murph, Charles; Bauchan, Gary; and Lo, Y. Martin, "Antibacterial Activity of Cinnamaldehyde And Sporan Against Escherichia Coli 0157:H7 And Salmonella" (2012). Publications from USDA-ARS / UNL Faculty. 1136.

https://digitalcommons.unl.edu/usdaarsfacpub/1136

This Article is brought to you for free and open access by the U.S. Department of Agriculture: Agricultural Research Service, Lincoln, Nebraska at DigitalCommons@University of Nebraska - Lincoln. It has been accepted for inclusion in Publications from USDA-ARS / UNL Faculty by an authorized administrator of DigitalCommons@University of Nebraska - Lincoln. 


\section{Authors}

Nadine Yossa, Jitendra Patel, Dumitru Macarisin, Patricia Millner, Charles Murph, Gary Bauchan, and Y. Martin Lo 


\title{
ANTIBACTERIAL ACTIVITY OF CINNAMALDEHYDE AND SPORAN AGAINST ESCHERICHIA COLI 0157:H7 AND SALMONELLA
}

\author{
NADINE YOSSA ${ }^{1}$, JITENDRA PATEL ${ }^{2,4}$, DUMITRU MACARISIN², PATRICIA MILLNER ${ }^{2}$, CHARLES MURPHY3, \\ GARY BAUCHAN ${ }^{3}$ and Y. MARTIN LO ${ }^{1}$
}

\author{
'Department of Nutrition and Food Science, University of Maryland, College Park, MD \\ ${ }^{2}$ Environmental Microbial and Food Safety Laboratory, Beltsville Agricultural Research Center (BARC), United States Department of Agriculture - \\ Agricultural Research Service (USDA-ARS), 10300 Baltimore Avenue, Bldg. 201, BARC-East, Beltsville, MD 20705 \\ ${ }^{3}$ Electron and Confocal Microscopy Unit, USDA-ARS, Beltsville, MD
}

\author{
${ }^{4}$ Corresponding author. TEL: 301-504-7003; \\ FAX: 301-504-8438; EMAIL: \\ jitu.patel@ars.usda.gov
}

Accepted for Publication August 21, 2012

doi:10.1111/jfpp.12026

\begin{abstract}
The in vitro antimicrobial effect of cinnamaldehyde and Sporan in combination with acetic acid against Escherichia coli O157:H7 and Salmonella was investigated in Luria-Bertani broth $(7 \log \mathrm{cfu} / \mathrm{mL})$ containing cinnamaldehyde or Sporan $(800$ and 1,000 ppm) alone or in combination with $200 \mathrm{ppm}$ acetic acid, and incubated at $37 \mathrm{C}$ for up to $6 \mathrm{~h}$. Surviving populations of test pathogens were determined by spiral plating on selective media. E. coli O157:H7 and Salmonella were undetectable after $1 \mathrm{~h}$ in the presence of $800 \mathrm{ppm}$ cinnamaldehyde. A 1,000 ppm Sporan significantly reduced Salmonella and E. coli O157:H7 populations by 1.83 and 3.02 $\log \mathrm{cfu} / \mathrm{mL}$ within 2 and $4 \mathrm{~h}$, respectively. Scanning and transmission electron microscopy of oil-treated bacterial cells revealed cell structural damage and leakage of cellular content. Cinnamaldehyde was highly effective against both E. coli O157:H7 and Salmonella whereas the effect of Sporan was dependent on its concentration, exposure time and pathogen.
\end{abstract}

\section{PRACTICAL APPLICATIONS}

Consumers' preference for fewer chemicals in food has led to research on potential use of natural antimicrobials in food for controlling spoilage and pathogenic microorganisms. The antimicrobial effect of essential oils has been studied earlier. This is the first report on the antimicrobial activity of Sporan, and the combined effect of acetic acid. The results of the present study indicate that the antimicrobial activity of cinnamaldehyde and Sporan against enteric pathogens could be useful in food processing and preservation.

\section{INTRODUCTION}

Foodborne illnesses caused by the consumption of food contaminated with pathogenic bacteria have been a concern to public health (Burt and Reinders 2003; Oussalah et al. 2007). From 2000 to 2008, Salmonella alone caused 380 deaths, 19,000 hospitalizations and 1 million illnesses in the United States. Although, the number of infections with Escherichia coli O157:H7 decreased, E. coli O157:H7 still remains a concern; it ranked fifth in causing 63,000 illnesses, 2,100 hospitalizations and 20 deaths in the United
States (Scallan et al. 2011). The battle against these bacteria remains challenging because they contaminate diverse foods; Salmonella can be found in poultry, eggs, ground meat, fruits, vegetables, and processed foods such as frozen pot pies and peanuts (CDC 2011a). E.coli O157:H7 has been detected from ground meat, poultry, fruits, leafy greens, dough and processed foods such as pizza (CDC 2011b).

The antimicrobial properties of some essential oils and their components have been described earlier (Shelef 1983; Nychas 1995). Recent studies have determined the 
antimicrobial activity of cinnamaldehyde, cloves, thyme, and rosemary against E. coli O157:H7 and Salmonella (Hammer et al. 1999; Del Campo et al. 2000; Rhayour et al. 2003; Kim et al. 2004; Oussalah et al. 2007). Thyme and clove oils disintegrate the outer membrane of gramnegative bacteria releasing lipopolysaccharides and increasing the permeability of the cytoplasmic membrane (Lambert et al. 2001; Devi et al. 2010). Wendakoon and Sakaguchi (1995) reported that the carbonyl group of cinnamaldehyde binds to the proteins, preventing amino acid decarboxylase activity in Enterobacter aerogenes. Smid et al. (1996) observed the damage to cytoplasmic membrane of Saccharomyces cerevisiae when treated with cinnamaldehyde, leading to excessive leakage of metabolites and enzymes from the cell, and finally loss of viability. We evaluated the effects of cinnamaldehyde and Sporan, a proprietary blend of $10 \%$ clove, $18 \%$ rosemary, and $10 \%$ thyme oils against E. coli O157:H7 and Salmonella strains in vitro. The effect of these oils on E. coli and Salmonella cell structure was observed through the scanning electron microscopy (SEM) and transmission electron microscopy (TEM).

\section{MATERIALS AND METHODS}

\section{Bacteria and Essential Oils}

Five nalidixic acid-resistant strains of E. coli O157:H7 and five Salmonella strains were used in the study. The strains of E. coli O157:H7 RM 4406, RM 4688 and RM 1918 (clinical isolates from lettuce outbreaks), RM 4407 (clinical isolate from spinach outbreak), and RM 5279 (clinical isolate, bagged vegetable isolate, outbreak) were used from our Environmental Microbial and Food Safety Laboratory culture collection. Five Salmonella enterica serovars, $S$. Braenderup (CDC clinical isolate), S. Newport, S. Negev 26 $\mathrm{H}$ (thyme isolates), S. Thompson $2051 \mathrm{H}$ and $S$. Tennessee $2053 \mathrm{~N}$, were used from our culture collection. A dam mutant Salmonella MT 2195 and E. coli O157:H7 B6914 strains were used for SEM and TEM studies.

Cinnamaldehyde (Sigma-Aldrich, St. Louis, MO) and Sporan (EcoSMART Technologies, Alpharetta, GA) were used to prepare 800 and 1,000 ppm cinnamaldehyde (800C, 1000C) and Sporan (800S, 1000S) in Luria-Bertani Broth (LB, Acumedia, Lansing, MI, supplemented with $50 \mathrm{ppm}$ nalidixic acid for E. coli, LBN). The concentrations were selected based on the minimum inhibitory concentration of cinnamaldehyde $(800 \mathrm{ppm})$. Additionally, these oils were used in combination with acetic acid (20\%, Fleischmann's Inc., Baltimore, MD) as $800 \mathrm{ppm}$ cinnamaldehyde $+200 \mathrm{ppm}$ acetic acid (1000CV) and $800 \mathrm{ppm}$ Sporan +200 ppm acetic acid (1000SV).

\section{Effect of Cinnamaldehyde and Sporan on the Viability of Nalidixic Acid-Resistant E. coli 0157:H7 and Salmonella}

Bacterial cells were grown overnight in LB or LBN at 37C. The actively growing overnight cultures were centrifuged $(7,500 \times \mathrm{g}, 10 \mathrm{~min}$ at $10 \mathrm{C})$ and washed in $0.1 \mathrm{M}$ sterile phosphate buffer solution (phosphate buffer saline [PBS], $\mathrm{pH}$ 7.0). Bacterial populations of each strain were estimated by measuring the optical density at $600 \mathrm{~nm}$ and cocktails of Salmonella and E. coli O157:H7 strains were prepared using equal volume of five strains. About $3 \mathrm{~mL}$ of the cocktail $(\sim 7$ $\log \mathrm{cfu} / \mathrm{mL}$ ) was transferred to $27 \mathrm{~mL} \mathrm{LB}$ broth containing 800 and 1,000 ppm of cinnamaldehyde or Sporan alone or in combination with $200 \mathrm{ppm}$ acetic acid, and incubated at $37 \mathrm{C}$ in shaker incubator $(75 \mathrm{gpm})$ for $6 \mathrm{~h}$. Samples $(1 \mathrm{~mL})$ pulled every hour were centrifuged at $12,000 \mathrm{rpm}$ for $5 \mathrm{~min}$, washed with PBS, and spiral plated on Sorbitol MacConkey media (Acumedia) supplemented with $0.05 \mathrm{mg} / \mathrm{L}$ of cefixime, $2.5 \mathrm{mg} / \mathrm{L}$ of potassium tellurite and $50 \mathrm{ug} / \mathrm{mL}$ nalidixic acid (CTSMAC-N, Sigma-Aldrich) for E. coli O157:H7 and on XLT4 agar (Acumedia) for Salmonella, in duplicate. Cells suspended in LB or LBN without oils were used as control.

\section{SEM}

Actively growing E. coli O157:H7 B6914 and Salmonella MT 2195 cells were harvested by centrifugation as described above and washed with sterile water. About $5 \mathrm{~mL}$ of sterile Tryptic soy broth containing an aliquot of cinnamaldehyde, Sporan and Sporan + acetic acid was added to the cell pellet and incubated for $3 \mathrm{~h}$ at $37 \mathrm{C}$. Following incubation, bacterial cells were washed three times with sterile water and observed under microscopy.

Low-temperature SEM observations were performed using an S-4700 field emission scanning electron microscope (Hitachi High Technologies America, Inc., Pleasanton, CA) equipped with a Quorum CryoPrep PP2000 (Quorum Technologies, Ltd., East Sussex, U.K.) cryotransfer system. Bacteria were transferred onto filter paper (Whatman \#1) attached with a thin layer of Tissue Tek (OCT Compound, Ted Pella, Inc., Redding, CA), which acted as the cryo-adhesive upon freezing to a flat specimen holder consisting of $16 \times 30 \mathrm{~mm}$ copper plate. The samples were frozen conductively in a Styrofoam box by placing the plates on the surface of a precooled (-196C) brass bar whose lower half was submerged in liquid nitrogen $\left(\mathrm{LN}_{2}\right)$. After 20-30 s, the holders containing the frozen samples were transferred to a $\mathrm{LN}_{2}$ Dewar for future use or cryotransferred under vacuum to the cold stage in the prechamber of the cryotransfer system. Removal of any surface contamina- 


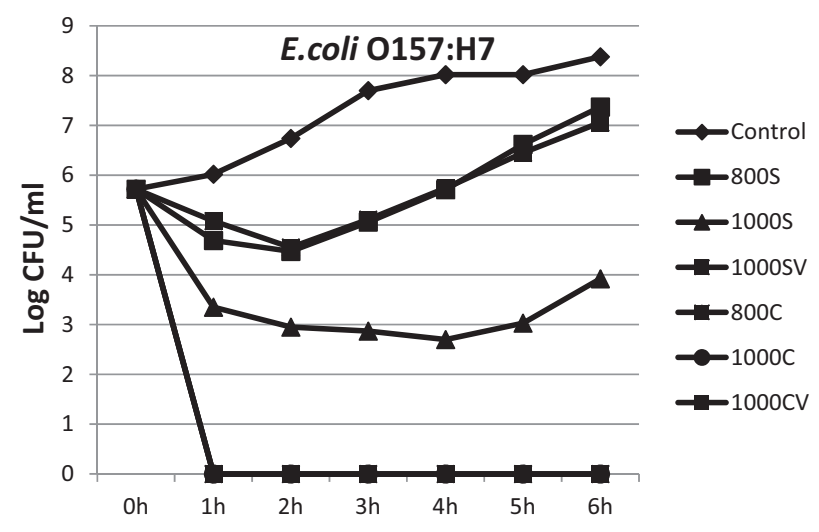

FIG. 1. ESCHERICHIA COLI O157:H7 POPULATIONS IN LURIA-BERTANI BROTH TREATED WITH ANTIMICROBIALS AND INCUBATED AT 37C FOR $6 \mathrm{H}$

The values are the means of three replications. $800 \mathrm{C}-800 \mathrm{ppm}$ cinnamaldehyde; $800 \mathrm{~S}-800$ ppm Sporan; $1000 \mathrm{C}-1,000$ ppm cinnamaldehyde; $1000 \mathrm{CV}-800 \mathrm{ppm}$ cinnamaldehyde +200 ppm acetic acid; $1000 \mathrm{~S}-1,000$ ppm Sporan; $1000 \mathrm{SV}-800$ ppm Sporan +200 ppm acetic acid.

tion (condensed water vapor) took place in the cryotransfer system by etching the frozen specimens for 10-15 min by raising the temperature of the stage to $-90 \mathrm{C}$. Following etching, the temperature was lowered below $-130 \mathrm{C}$, and a magnetron sputter head equipped with a platinum target was used to coat the specimens with a very fine layer of platinum. The specimens were transferred to a precooled $(-140 \mathrm{C})$ cryostage in the SEM for observation. An accelerating voltage of $5 \mathrm{kV}$ was used to view the specimens. Images were captured using a 4pi Analysis System (Durham, NC).

\section{TEM}

Bacterial cells were fixed for $1 \mathrm{~h}$ at room temperature by immersion in $3 \%$ glutaraldehyde/ $0.05 \mathrm{M} \mathrm{Na}$ cacodylate buffer ( $\mathrm{pH}$ 7.0). This was followed by washing in a $0.05 \mathrm{M}$ $\mathrm{Na}$ cacodylate buffer, rinsed three times over $1 \mathrm{~h}$, postfixed in $2 \%$ buffered osmium tetroxide for $2 \mathrm{~h}$, dehydrated in ETOH and infiltrated with Spurrs low-viscosity embedding resin. About $60-90-\mathrm{nm}$ silver-gold sections of the tissue were cut on a Reichert/AO Ultracut microtome with a Diatome diamond knife and mounted onto 400 mesh $\mathrm{Ni}$ grids. They were stained with $4 \%$ uranyl acetate and 3\% lead citrate and viewed in an HT-7700 Hitachi Microscope at $80 \mathrm{kV}$.

\section{Statistical Analysis}

The experiment was repeated three times for in vitro antimicrobial effect of cinnamaldehyde and Sporan at each exposure time. Surviving populations of E. coli O157:H7 and Salmonella were converted to $\log \mathrm{cfu} / \mathrm{mL}$ and were compared among antimicrobial-exposure time combinations by a three-way analysis of variance using "proc-mixed" and "Tukey" procedure (SAS 9.2, Cary, NC). The level of statistical significance was set at $P<0.05$ in all cases.

\section{RESULTS \\ Effect of Cinnamaldehyde and Sporan on the Viability of E. coli 0157:H7 and Salmonella}

The growth curves of nalidixic acid-resistant E. coli O157:H7 and Salmonella in LB broth containing cinnamaldehyde and Sporan are shown in Figs. 1 and 2.

E. coli O157:H7 populations in control LB broth increased from 5.72 to $8.38 \mathrm{log} \mathrm{cfu} / \mathrm{mL}$ during the 6 -h incubation at 37C. All treatments reduced E. coli O157:H7 at $1 \mathrm{~h}$. The effect of $800 \mathrm{C}, 1000 \mathrm{C}$ and $1000 \mathrm{CV}$ on E. coli O157:H7 was bactericidal within $1 \mathrm{~h}$, the E. coli O157:H7 populations were undetectable in $1 \mathrm{~h}$ (detection limit $1 \mathrm{log}$ $\mathrm{cfu} / \mathrm{mL})$. E. coli $\mathrm{O} 157: \mathrm{H} 7$ populations were reduced by ca. $1.25 \log \mathrm{cfu} / \mathrm{mL}(P>0.05)$ during the first $2 \mathrm{~h}$ of incubation followed by increase in their populations when treated with 800 ppm Sporan alone or in combination with acetic acid. Nevertheless, populations after 3 and $4 \mathrm{~h}$ in 800S-treated LB broth $(5.06$ and $5.71 \log \mathrm{cfu} / \mathrm{mL})$ and 1000SV-treated LB broth $(5.11$ and $5.74 \log \mathrm{cfu} / \mathrm{mL}$ ) were significantly lower than those in control (7.70 and $8.02 \log \mathrm{cfu} / \mathrm{mL})$, respectively. Significant reductions in E. coli O157:H7 populations were observed throughout the 6 -h period when treated with

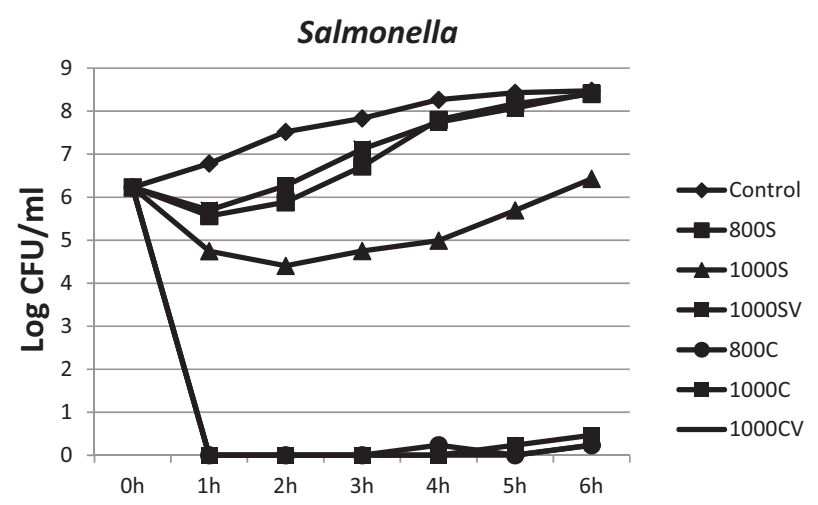

FIG. 2. SALMONELLA POPULATIONS IN LURIA-BERTANI BROTH TREATED WITH ANTIMICROBIALS AND INCUBATED AT 37C FOR $6 \mathrm{H}$ The values are the means of three replications. $800 \mathrm{C}-800 \mathrm{ppm}$ cinnamaldehyde; $800 \mathrm{~S}-800 \mathrm{ppm}$ Sporan; $1000 \mathrm{C}-1,000 \mathrm{ppm}$ cinnamaldehyde; $1000 \mathrm{CV}-800 \mathrm{ppm}$ cinnamaldehyde $+200 \mathrm{ppm}$ acetic acid; $1000 \mathrm{~S}-1,000$ ppm Sporan; $1000 \mathrm{SV}-800$ ppm Sporan +200 ppm acetic acid. 

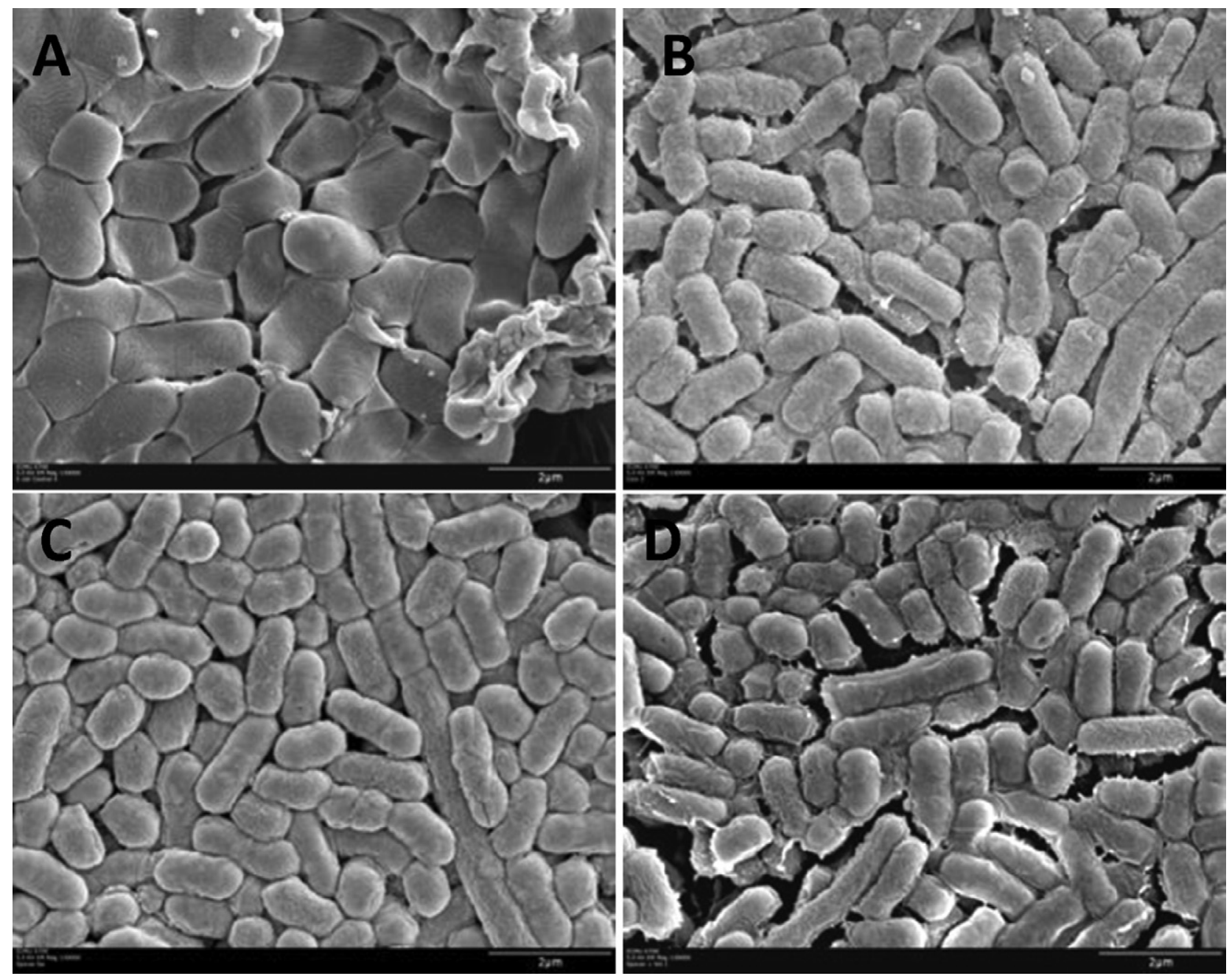

FIG. 3. SCANNING ELECTRON MICROSCOPY OF ESCHERICHIA COLI B6914 CELLS AFTER A 3-H TREATMENT WITH CINNAMALDEHYDE, SPORAN AND SPORAN-ACETIC ACID

(A) Untreated cells; cells treated with (B) $0.4 \%$ cinnamaldehyde, (C) $0.4 \%$ Sporan and (D) $0.36 \%$ Sporan $+0.04 \%$ acetic acid. Scale bar $=2 \mu \mathrm{m}$

1,000 ppm Sporan. E. coli O157:H7 populations in 1000Streated LB broth were 4.83, 5.32, 4.99 and $4.46 \log \mathrm{cfu} / \mathrm{mL}$, which were significantly lower than their corresponding controls at 3, 4, 5 and $6 \mathrm{~h}$, respectively.

Likewise, the populations of Salmonella in control LB broth increased from 6.23 to $8.48 \mathrm{log} \mathrm{cfu} / \mathrm{mL}$ during the 6-h incubation period (Fig. 2). Similar to E. coli O157:H7 results, the effects of cinnamaldehyde at all concentrations were bactericidal within $1 \mathrm{~h}$. Nevertheless, a marginal growth of Salmonella populations of $0.23-0.47 \log \mathrm{cfu} / \mathrm{mL}$ was observed in cinnamaldehyde-treated LB broth at 5-6 h. Salmonella populations were increased in 800S- and 1000SV-treated LB broth after $2 \mathrm{~h}$, the difference in Salmonella populations of $800 \mathrm{~S}$ - and 1000SV-treated LB broth was not significant from those of control LB broth at 4-6 h. Salmonella populations were reduced by $1.83 \mathrm{cfu} / \mathrm{mL}$ within
$2 \mathrm{~h}$ in 1000S-treated LB broth followed by an increase to reach the initial inoculum level (ca. $6.23 \mathrm{cfu} / \mathrm{mL}$ ). Salmonella populations in 1000S-treated LB broth after 2, 3, 4 and $5 \mathrm{~h}(4.40,4.75,4.99$ and $5.69 \log \mathrm{cfu} / \mathrm{mL})$, respectively, were significantly lower than their corresponding controls.

The effect of 800 ppm Sporan was insignificant irrespective of the presence of acetic acid.

\section{SEM and TEM Investigation of the Effect of Cinnamaldehyde and Sporan on E. coli 0157:H7 Cell Surface}

SEM images of treated E. coli O157:H7 showed different surface patterns than the untreated control (Fig. 3). The untreated cells presented a wavelike structures, whereas the 

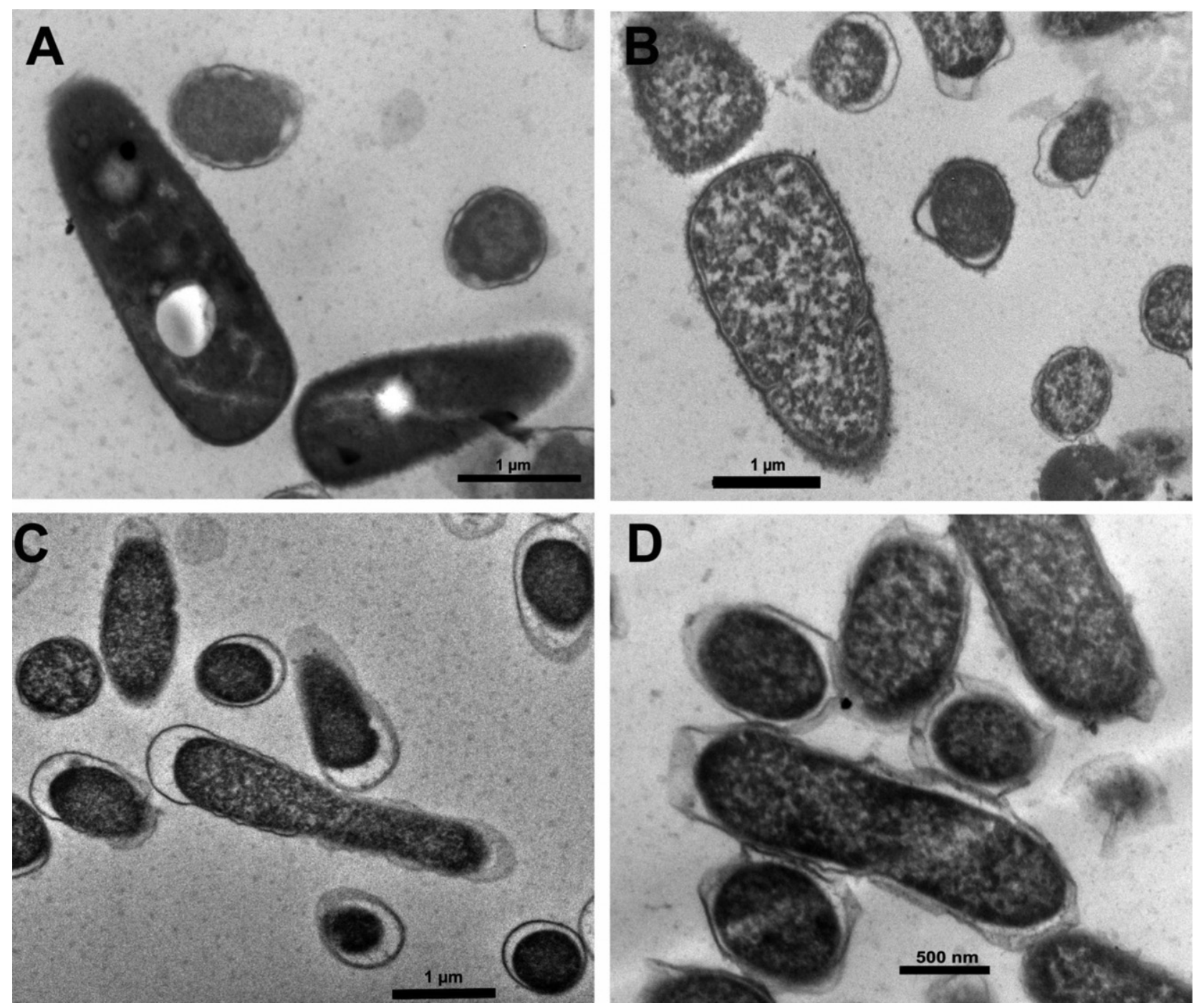

FIG. 4. TRANSMISSION ELECTRON MICROSCOPY OF ESCHERICHIA COLI B6914 CELLS AFTER 3-H TREATMENT WITH CINNAMALDEHYDE, SPORAN AND SPORAN-VINEGAR

Images are viewed in HT-7700 Hitachi Microscope at $80 \mathrm{kV}$. (A) Untreated cells; cells treated with (B) $0.4 \%$ cinnamaldehyde, (C) $0.4 \%$ Sporan and (D) $0.36 \%$ Sporan $+0.04 \%$ acetic acid.

treated cells showed surface deformation. E. coli O157:H7 cells treated with cinnamaldehyde, Sporan and Sporan + acetic acid appeared wrinkled and shrunken, including morphological rod alterations. In addition, some cells treated with cinnamaldehyde or Sporan + acetic acid were transparent. Likewise, TEM image of E. coli B1914 (Fig. 4) of untreated cells showed no alterations of the internal structures whereas treated cells exhibited a granulated surface for some cells, deformation and even disruption of the outer membrane for other cells.

Similarly, SEM images of treated Salmonella cells showed morphological alterations (Fig. 5). When compared to untreated cells, all treated cells collapsed and appeared empty of contents. On the other hand, images of TEM of Salmonella cells (Fig. 6) revealed a severe damage caused by the antimicrobial treatment. Cells treated with cinnamaldehyde, Sporan and Sporan + acetic acid showed either empty contents without visible changes in the outer membrane, disruption of the plasma membrane, or cell wall lysis.

\section{DISCUSSION}

Essential oils are the odorous volatile products of an aromatic plant's secondary metabolism, found in leaves, barks, and fruits, and when they occur in various organs in the same plant, they frequently have different composition pro- 

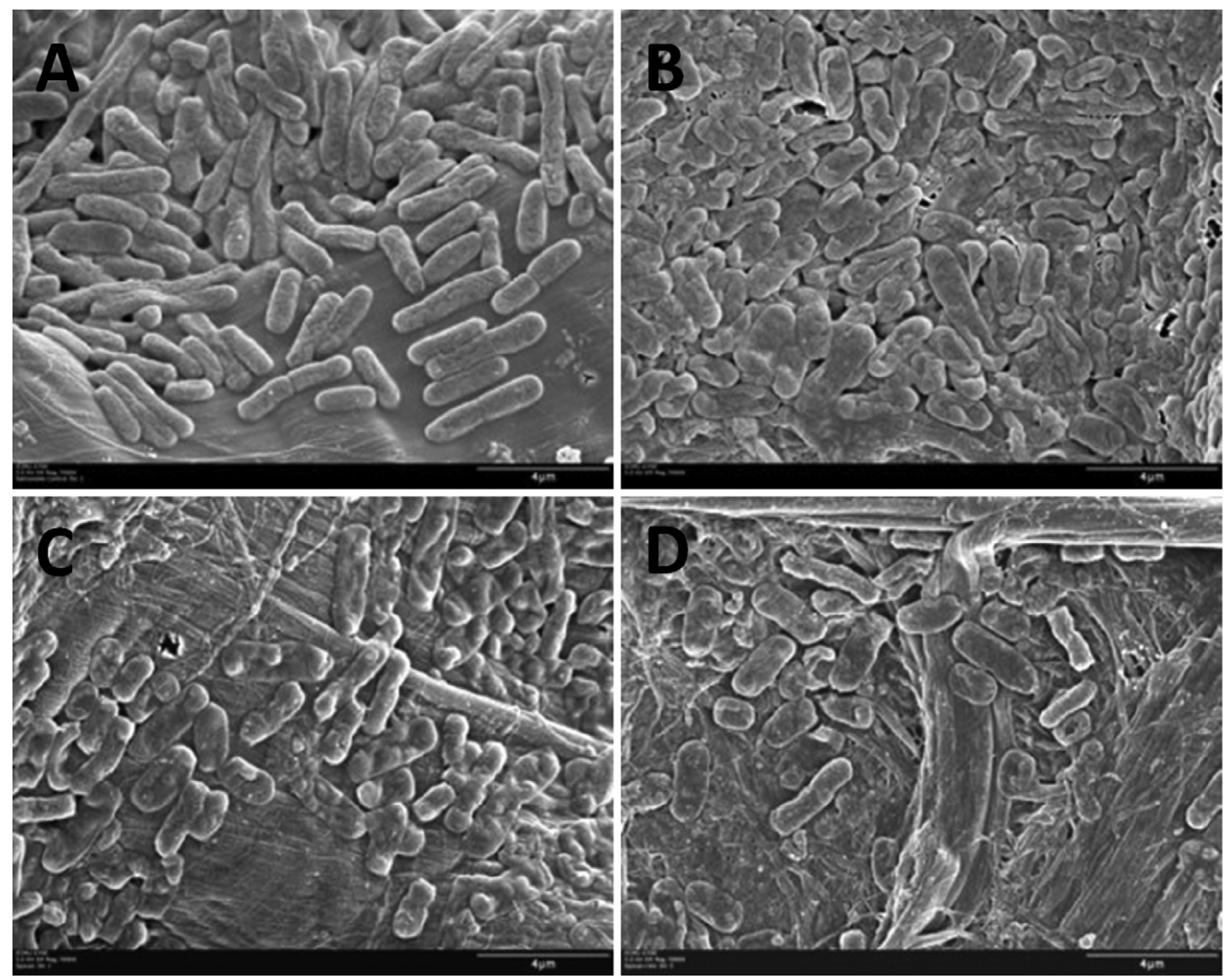

FIG. 5. SCANNING ELECTRON MICROSCOPY OF SALMONELLA MT 2195 CELLS AFTER A 3-H TREATMENT WITH CINNAMALDEHYDE, SPORAN AND SPORAN-VINEGAR

Images were viewed in S-4700 Hitachi. (A) Untreated cells; cells treated with (B) $0.4 \%$ cinnamaldehyde, (C) $0.4 \%$ Sporan and (D) $0.36 \%$ Sporan $+0.04 \%$ acetic acid. Scale bar $=4 \mu \mathrm{m}$.

files (Oussalah et al. 2007). Recently, antimicrobial effects of essential oils against bacteria, yeasts, fungi and viruses have been reported (Reichling et al. 2009). The major active essential oil components are phenols, terpenes and aldehydes (Ceylan and Fung 2004), which mainly damage the cell cytoplasmic membrane (Sikkema et al. 1995; Di Pasqua et al. 2007).

In this study, cinnamaldehyde exhibited strong antimicrobial properties on E. coli O157:H7 and Salmonella. Our results are in agreement with Kim etal. (2004) who observed complete inhibition of E. coli O157:H7 in LB containing 1,000 ppm of cinnamaldehyde after $2 \mathrm{~h}$. Ali et al. (2005) observed $3.5 \mathrm{log}$ reduction of E. coli O157:H7 in broth containing $1 \mathrm{ppm}$ cinnamaldehyde after $75 \mathrm{~min}$. Likewise, Helander et al. (1998) reported inhibition of E. coli and Salmonella Typhimurium at 132-396 ppm cinnamaldehyde in LB broth. Cinnamaldehyde is a highly effective fungicidal agent (Smid et al. 1996) with minimal mammalian toxicity (Jenner et al. 1964). On the other hand, the inhibitions of bacterial cells by Sporan (blend of clove, rosemary and thyme oil) were dependent on its concentration, exposure time and test pathogen. Combination of acetic acid with Sporan to the treatment did not improve its antimicrobial effects.

SEM images of untreated E. coli O157:H7 and Salmonella cells revealed a surface with wrinkled protrusions, naturally present structures on the surface of living bacteria. Similar observations of intact cells were reported by Greif et al. (2010). In our study, the cell membranes of E. coli O157:H7 were severely affected by antimicrobial treatments rather 

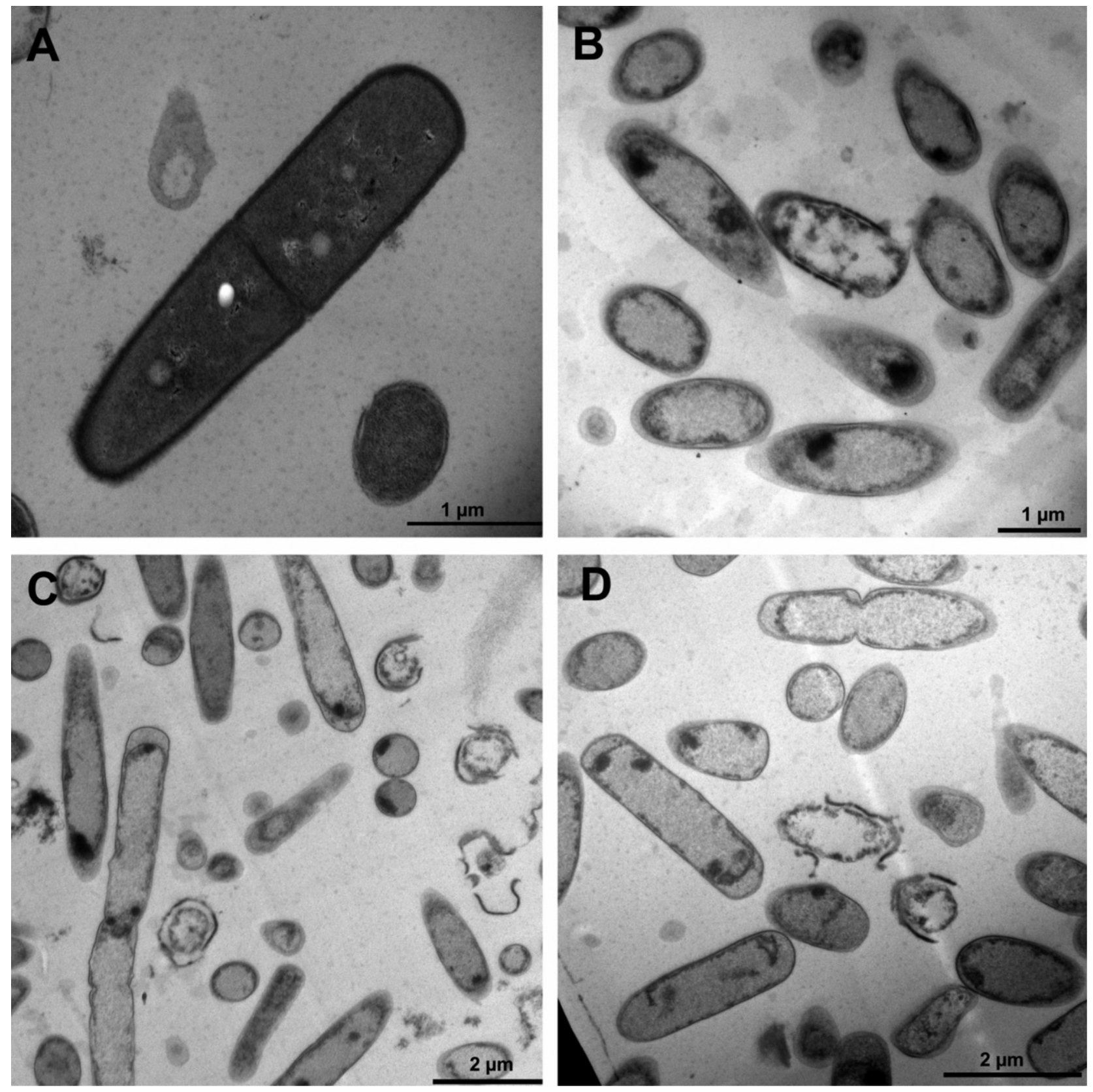

FIG. 6. TRANSMISSION ELECTRON MICROSCOPY OF SALMONELLA MT 2195 CELLS AFTER 3-H TREATMENT WITH CINNAMALDEHYDE, SPORAN AND SPORAN-VINEGAR

Images are viewed in HT-7700 Hitachi Microscope at $80 \mathrm{kV}$. (A) Untreated cells; cells treated with (B) $0.4 \%$ cinnamaldehyde, (C) $0.4 \%$ Sporan and (D) $0.36 \%$ Sporan $+0.04 \%$ acetic acid.

than its cellular content. This finding is in agreement with those of Di Pasqua et al. (2007) who stipulated that cinnamaldehyde and thymol caused structural alteration of the outer envelope in E. coli O157:H7. The E. coli O157:H7 cell envelopes of treated cells were transparent, indicating interactions of the antimicrobial compounds with the cell membranes. Helander et al. (1998) reported that cinnamal- dehyde penetrated to the periplasm and to the cell interior of gram-negative bacteria through outer membranetraversing porin proteins. E. coli O157:H7 cells treated with $625 \mathrm{ppm}$ oregano oil collapsed, resulting in leakage of cellular contents (Burt and Reinders 2003). Cinnamaldehyde and Sporan damaged the outer membrane of E. coli O157:H7 cells in our study. We speculate that the antimicrobial action 
of cinnamaldehyde and Sporan could be different from oregano oil, or the strain variation might have influenced differences in our results.

On the other hand, Salmonella seemed to be affected internally and externally. The penetration of antimicrobials in the cell envelope might have caused internal damage to the Salmonella cells. Our results are in agreement with Smid et al. (1996) who reported the disintegration of the cytoplasmic membrane of Saccharomyces cerevisiae, leading to excessive loss of viability. Cellular damage to Salmonella by cinnamaldehyde and Sporan was similar. Sporan has been reported to disrupt the cell membrane of fungal hyphae and spores (Anon 2008).

Most authors have suggested that the modes of action of essential oils depend on the type of microorganisms, mainly on their cell wall structure and to their outer membrane arrangement. They observed damages due to the significant differences in the outer membranes of gram-negative and gram-positive bacteria (Rhayour et al. 2003; Shan et al. 2007). In the light of our findings, SEM and TEM images showed us that essential oils could damage differently cells belonging to the same bacteria group. Despite these differences, the mechanism of action of cinnamaldehyde and Sporan involves the cell membrane. Some European countries have abandoned the use of hypochlorite for disinfection of foods; environmental friendly natural plant-derived antimicrobials with less mammalian toxicity could be better alternatives. This study shows that cinnamaldehyde and Sporan effectively eliminate or reduce bacterial cells. The effects of cinnamaldehyde and Sporan in reducing enteric pathogens on spinach leaves have been reported (Yossa et al. 2012). These antimicrobials can be further evaluated with different food (poultry, livestock food), water and irrigation water to control foodborne pathogens.

\section{REFERENCES}

ALI, S.M., KHAN, A.A., AHMED, I., MUSADDIQ, M., AHMED, K.S., POLASA, H., RAO, L.V., HABIBULLAH, C.M., SECHI, L. and AHMED, N. 2005. Antimicrobial activities of eugenol and cinnamaldehyde against the human pathogen Helicobacter pylori. Ann. Clin. Microbiol. Antimicrob. 4, 20-26.

Anonymous. 2008. Greenhouse grower. EcoSMART goes organic with insecticides. http://www.greenhousegrower.com/ news/?storyid=612 (accessed January 26, 2012).

BURT, S.A. and REINDERS, R.D. 2003. Antimicrobial activity of selected plant essential oils against Escherichia coli O157:H7. Lett. Appl. Microbiol. 36, 162-167.

CDC (CENTER FOR DISEASE CONTROL). 2011a. Multistate foodborne outbreaks. http://www.cdc.gov/outbreaknet/ outbreaks.html (accessed January 26, 2012).
CDC (CENTER FOR DISEASE CONTROL). 2011b. Salmonella outbreaks. http://www.cdc.gov/salmonella/outbreaks.html (accessed January 26, 2012).

CEYLAN, E. and FUNG, D.Y.C. 2004. Antimicrobial activity of spices. J. Rapid Methods Autom. Microbiol. 12, 1-55.

DEL CAMPO, D.J., AMIOT, M.J. and NGUYEN-THE, C. 2000. Antimicrobial effect of rosemary extracts. J. Food Prot. 10, 1359-1368.

DEVI, P., NISHA, S., SAKTHIVEL, R. and PANDIAN, K. 2010. Eugenol (an essential oil of clove) acts as an antibacterial agent against Salmonella Typhi by disrupting the cellular membrane. J. Ethnopharmacol. 130, 107-115.

DI PASQUA, R., BETTS, G., HOSKINS, N., EDWARDS, M., ERCOLINI, D. and MAURIELLO, G. 2007. Membrane toxicity of antimicrobial compounds from essential oils. J. Agric. Food Chem. 55, 4863-4870.

GREIF, D., WESNER, D., ANSELMETTI, D. and REGTMEIER, J. 2010. High-resolution imaging of dried and living single bacterial cell surfaces: Artifact or not? Ultramicroscopy 110, 1290-1296.

HAMMER, K.A., CARSON, C.F. and RILEY, T.V. 1999. Antimicrobial activity of essential oils and other plant extracts. J. Appl. Microbiol. 86, 985-990.

HELANDER, I.K., ALAKOMI, H.-L., LATVA-KALA, K., MATTILDA-SANDHOLM, T., POL, I., SMID, E.J., GORRIS, L.G.M. and VON WRIGHT, A. 1998. Characterization of the action of selected essential oil components on gram-negative bacteria. J. Agric. Food Chem. 46, 3590-3595.

JENNER, P.M., HAGAN, E.C., TAYLOR, J.M., COOK, E.L. and FITZHUGH, O.G. 1964. Food flavourings and compounds of related structure. Food Chem. Toxicol. 2, 327-343.

KIM, H.-O., PARK, S.-W. and PARK, H.-D. 2004. Inactivation of Escherichia coli O157:H7 by cinnamic aldehyde purified from Cinnamomum cassia shoot. Food Microbiol. 21, $105-110$.

LAMBERT, R.J.W., SKANDAMIS, P.N., COOTE, P. and NYCHAS, G.-J.E. 2001. A study of the minimum inhibitory concentrations and mode of action of oregano essential oil, thymol and carvacrol. J. Appl. Microbiol. 91, 453-462.

NYCHAS, G.J.E. 1995. Natural antimicrobials from plants. In New Methods of Food Preservation (G.W. Gould, ed.) pp. 58-89, Blackie Academic and Professional, London, U.K.

OUSSALAH, M., CAILLET, S., SAUCIER, L. and LACROIX, M. 2007. Inhibitory effects of selected plant essential oils on the growth of four pathogenic bacteria: E. coli O157:H7, Salmonella Typhimurium, Staphylococcus aureus and Listeria monocytogenes. Food Control 18, 414-420.

REICHLING, J., SCHNITZLER, P., SUSCHKE, U. and SALLER, R. 2009. Essential oils of aromatic plants with antibacterial, antifungal, antiviral, and cytotoxic properties - an overview. Forsch. Komplementmed. 16, 79-90.

RHAYOUR, K., BOUCHIKHI, T., TANTAOUI-ELARAKI, A., SENDIDE, K. and REMMAL, A. 2003. The mechanism of bactericidal action of oregano and clove essential oils of their 
phenolic major components on Escherichia coli and Bacillus subtilis. J. Essent. Oil Res. 15, 356-362.

SCALLAN, E., HOEKSTRA, R.M., ANGULO, F.J., TAUZE, R.V., WIDDOWSON, M.-A., ROY, S.L., JONES, J.F. and GRIFFIN, P.M. 2011. Foodborne illness acquired in the United States - major pathogens. Emerg. Infect. Dis. 17, 7-15.

SHAN, B., CAY, Y.-Z., BROOKS, J.D. and CORKE, H. 2007. Antibacterial properties and major bioactive components of cinnamon stick (Cinnamomum burmannii): Activity against foodborne pathogenic bacteria. J. Agric. Food Chem. 55, 5484-5490.

SHELEF, L. 1983. Antimicrobial effects of spices. J. Food Saf. 6, 29-44.
SIKKEMA, J., DE BONT, J.A.M. and POOLMAN, B. 1995. Mechanisms of membrane toxicity of hydrocarbons. Microbiol. Rev. 59, 201-222.

SMID, E.J., KOEKEN, J.P.G. and GORRIS, L.G.M. 1996. Fungicidal and fungistatic action of the secondary plant metabolites cinnamaldehyde and carvone. In Modern Fungicides and Antimicrobial Compounds (H. Lyr, P.E. Russell and H.D. Sisler, eds.) pp. 173-180, Intercept, Andover, U.K.

WENDAKOON, C. and SAKAGUCHI, M. 1995. Inhibition of amino acid decarboxylase activity of Enterobacter aerogenes by active components in spices. J. Food Prot. 58, 280-283.

YOSSA, N., PATEL, J.R., MILLNER, P. and LO, Y.M. 2012. Essential oils reduce Escherichia coli O157:H7 and Salmonella on spinach leaves. J. Food Prot. 75, 488-496. 